Article

\title{
In Vitro Anthelmintic Activity of Saponins from Medicago spp. Against Sheep Gastrointestinal Nematodes
}

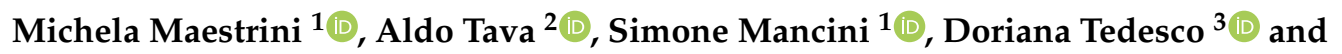 \\ Stefania Perrucci $1, *$ (D) \\ 1 Department of Veterinary Sciences, University of Pisa, viale delle Piagge 2, 56124 Pisa, Italy; \\ michela.maestrini@phd.unipi.it (M.M.); simone.mancini@unipi.it (S.M.) \\ 2 CREA Research Centre for Animal Production and Aquaculture; viale Piacenza 29, 26900 Lodi, Italy; \\ aldo.tava@crea.gov.it \\ 3 Department of Environmental Science and Policy, University of Milano, via Celoria 2, 20133 Milano, Italy; \\ doriana.tedesco@unimi.it \\ * Correspondence: stefania.perrucci@unipi.it; Tel.: +39-050-221-6949
}

Academic Editor: Stefano Dall'Acqua

Received: 17 December 2019; Accepted: 4 January 2020; Published: 7 January 2020

\begin{abstract}
Gastrointestinal strongyle nematodes (GIS) are included among the most important parasites of small ruminants. The widespread drug resistance and drug residues in products of animal origin have increased the interest in the search for natural compounds with anthelmintic activity as a valid alternative to current synthetic drugs. The aim of the present investigation was to test the 'in vitro' anthelmintic activity of saponins and prosapogenins from different Medicago species, selected for their importance as a forage crop worldwide for animal feeding. From these plants, saponin mixtures were extracted, purified and used at scalar concentrations to evaluate their anthelmintic activities against sheep gastrointestinal strongyles (GISs), by the egg hatch test. Treated and untreated controls were used as the comparison. Data were statistically analyzed, and $\mathrm{EC}_{50}$ and $\mathrm{EC}_{90}$ were also calculated. All saponins and prosapogenins showed inhibiting effects on GIS eggs in a concentration-dependent manner. At higher concentrations, most of them showed an efficacy comparable to the reference drug (Thiabendazole $3 \mu \mathrm{g} / \mathrm{mL})(P<0.001)$. With $1.72 \mathrm{mg} / \mathrm{mL} \mathrm{EC}_{50}$ and $3.84 \mathrm{mg} / \mathrm{mL} \mathrm{EC} 90$, saponin from M. polymorpha cultivars Anglona was the most active. Obtained results encourage further studies aimed at evaluating the efficacy 'in vivo' of saponins which resulted as most effective 'in vitro' in this study.
\end{abstract}

Keywords: saponins; prosapogenins; Medicago spp.; sheep; gastrointestinal strongyles; 'in vitro' anthelmintic activity

\section{Introduction}

Gastrointestinal strongyles (GIS) are considered one of the most common causes of economic losses and disease in small ruminant breeding [1]. These parasites are nematodes belonging to the Strongylida order, and localize in the gastrointestinal tract of small ruminants. Infected animals may show reduced growth, cachexia, weakness, anemia and diarrhea, that may lead to poor reproductive and productive performances and death [2]. In the last decades gastrointestinal strongyles infections have been primarily controlled with synthetic drugs belonging to different chemical classes, i.e., benzimidazoles, imidazothiazole/tetrahydroxypyrimidines, macrocyclic lactones, amino-acetonitrile derivates and spiroindoles [1]. However, the regular and sometimes excessive use of anthelmintics has contributed to the onset of drug resistance, which is now widespread worldwide [3], limiting the effectiveness of synthetic drugs for the control of gastrointestinal nematode infections [4,5]. Confirming this, there are 
reports of the reduced efficacy of some recently commercialized anthelmintics, such as monepantel or derquantel against the GIS species Haemonchus contortus [6]. Therefore, to date, many anthelmintics prove to be inefficacious, as well as polluting [7]. Another important issue linked to the use of synthetic drugs is that their residues can be found in products of animal origin, such as meat and milk [8].

For the control of GIS there are various environmentally sustainable, non chemical approaches that can limit the use of synthetic drugs in ruminants, such as vaccination, biological control, nutritional supplementation and grazing management, including pasture rotation [9], but in most cases the complementary aid of an anthelminthic treatment is still required [10]. For this reason, there is an increasing interest in natural compounds with anthelmintic activity, such as plant extracts and plant-derived compounds, with the aim to find a valid alternative to current synthetic drugs, or that can be used as a model for the synthesis of new drugs. Several previous 'in vitro' and 'in vivo' studies in small ruminants have shown that different plant extracts and pure compounds of plant origin possess anthelmintic properties against GIS species, including two of the most pathogenic common nematodes of small ruminants, i.e., Haemonchus contortus [11,12] and Teladorsagia circumcincta [13]. The anthelmintic activity of these plant extracts is related to the presence of biologically active metabolites such as condensed tannins, flavonoids, steroids, terpenoids, alkaloids and saponins $[14,15]$. Among these, saponins are important secondary metabolites from plants, and are considered as potential anthelmintic natural compounds $[16,17]$. It is reported that fractions rich in steroidal and triterpenic saponins from Agave sisalana have an 'in vitro' ovicidal effect against the nematodes of goats [18]. More recently, the 'in vitro' nematicidal potential of saponins from different Medicago spp. against donkey nematodes was demonstrated [19]. Biological effects of saponins are normally ascribed to their specific interaction with cell membranes [20], causing changes in cell permeability. By affecting some cell membrane components, saponins induce the formation of micelle-like aggregates that disrupt membrane functionality and cause lysis [21]. For nematodes, saponins have been associated with the formation of complexes with cellular membrane components present in different stages of the nematode life cycle, leading to an increase in membrane permeability and causing these parasites to die [21,22]. Saponins are detected in many plant species, including the genus Medicago, in which they are triterpenic pentacyclic glycosides with a wide range of biological properties, including antimicrobial, fungicidal, nematicidal, cytotoxic and insecticidal activities [20,23-26].

The aim of the present investigation was to test 'in vitro' the anthelmintic activity of saponins and prosapogenins from different Medicago species, selected for their importance as a forage crop worldwide for animal feeding. Alfalfa, M. sativa L. and burr medic, M. polymorpha L. have been considered as species that have an agronomic relevance in Mediterranean environments [27]. From these forage plants, saponin mixtures were extracted, purified and used at different concentrations to assess their 'in vitro' anthelmintic activities against GIS of sheep, by using the egg hatch test (EHT), that evaluates the ability of a compound to inhibit the development and the hatch of GIS eggs.

\section{Results}

\subsection{Saponin Composition}

The compositional profile of Medicago saponin extracts used in this study differed according to the plant species [28-30]. Crude saponins were obtained from the Medicago species under investigation as whitish powder in a purity of about $90 \%$ and in a different yield: M. polymorpha cv. Anglona $2.1 \%$ dry matter (DM), M. polymorpha cv. Santiago 1.7\% DM and M. sativa cv. Equipe 1.5\% DM. Figure 1 shows the chemical structure of the most abundant saponins/sapogenins detected in the different Medicago extracts. The content of the most abundant sapogenins, obtained after acid hydrolysis of the corresponding glycosides, is reported in Table 1 .

Saponins from $M$. sativa were characterized by a higher amount of medicagenic and zanhic acids (Figure 1), quoted as $47.2 \%$ and $25.5 \%$ of the total sapogenins, respectively. Hederagenin (Figure 1) was instead the dominant sapogenin in M. polymorpha cv. Santiago, representing $88.3 \%$ of the total aglycones, 
while echinocystic acid (90.1\%) (Figure 1) was the dominant sapogenin detected in M. polymorpha cv. Anglona. Soyasapogenol B, the aglycone moiety of soyasaponin I, a saponin commonly present in Leguminosae, was detected in all samples, although in a different amount. From the high-performance liquid chromatography (HPLC) analyses of saponins (data not shown), and by comparison with authentic reference compounds previously identified in the Medicago spp. [30-32], all the saponin mixtures here evaluated were mainly constituted by bidesmosidic type saponins (70\%-80\%). M. sativa prosapogenins, obtained after basic hydrolysis of the corresponding saponins, were instead entirely made up by monodesmosides and possess the same sapogenin composition as M. sativa from which they were obtained.
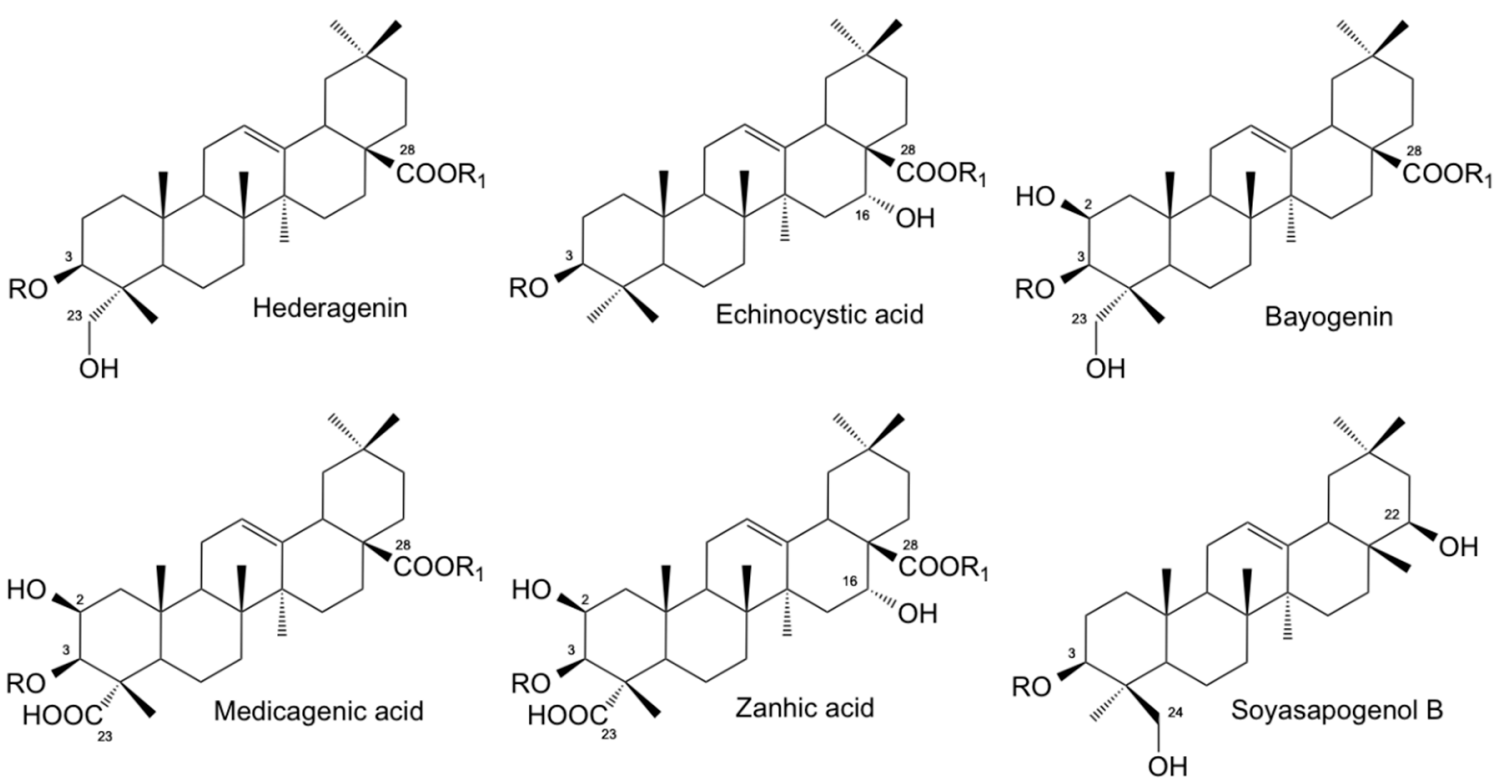

Figure 1. Chemical structure of the most abundant sapogenins $\left(R=R_{1}=H\right)$ detected in the Medicago spp. used in this study. $R=R_{1}=$ sugar or sugar chain: bidesmosidic saponins; $R=$ sugar or sugar chain, $\mathrm{R}_{1}=\mathrm{H}$ : monodesmosidic saponins.

Table 1. Percentage composition of the most abundant sapogenins detected in the Medicago saponin mixtures used in this investigation. For chemical structures see Figure 1.

\begin{tabular}{cccc}
\hline Sapogenin & $\begin{array}{c}\text { M. polymorpha cv. } \\
\text { Anglona }\end{array}$ & $\begin{array}{c}\text { M. polymorpha cv. } \\
\text { Santiago }\end{array}$ & M. sativa cv. Equipe \\
\hline Hederagenin & 3.6 & 88.3 & 1.1 \\
Echinoystic acid & 90.1 & 2.8 & - \\
Bayogenin & 0.2 & 3.2 & 1.8 \\
Medicagenic acid & - & - & 47.2 \\
Zanhic acid & - & - & 25.5 \\
Soyasapogenol B & 2.1 & 3.6 & 13.3 \\
\hline
\end{tabular}

\section{2. 'In Vitro' Anthelmintic Activity of Saponin Mixtures}

Results of the 'in vitro' anthelmintic activity of the saponin mixtures tested at different concentrations against sheep GIS eggs are reported in Figure 2. All the saponin mixtures used in this study showed inhibiting effects against GIS eggs in a concentration-dependent manner. More specifically, 10, 5 and $2.5 \mathrm{mg} / \mathrm{mL}$ M. polymorpha cv. Anglona, 10 and $5 \mathrm{mg} / \mathrm{mL}$ M. polymorpha cv. Santiago and $10 \mathrm{mg} / \mathrm{mL}$ M. sativa saponins were able to inhibit almost $100 \%$ of GIS eggs. For these saponin samples the same anthelmintic effects were recorded as for the reference drug, thiabendazole (TBZ), tested at $3 \mu \mathrm{g} / \mathrm{mL}(P<0.001)$. 
A very good inhibition activity (93\%) was also observed for M. polymorpha cv Santiago at $2.5 \mathrm{mg} / \mathrm{mL}$, while the efficacy of 0.5 and $0.25 \mathrm{mg} / \mathrm{mL}$ M. polymorpha cv. Anglona, $0.5 \mathrm{mg} / \mathrm{mL}$ M. polymorpha $\mathrm{cv}$ Santiago, 5 and $2.5 \mathrm{mg} / \mathrm{mL} M$. sativa saponins and $10 \mathrm{mg} / \mathrm{mL}$ M. sativa prosapogenins ranged between $73 \%$ and $84 \%$ (Figure 2). Egg hatching inhibition values comprised between $43 \%$ and $66 \%$ were observed for M. polymorpha cv. Santiago at $0.25 \mathrm{mg} / \mathrm{mL}, M$. sativa saponins at $0.5 \mathrm{mg} / \mathrm{mL}$ and $M$. sativa prosapogenins in the range $5-0.5 \mathrm{mg} / \mathrm{mL}$ concentration. All other saponin solutions $(0.05 \mathrm{mg} / \mathrm{mL}$ M. polymorpha cv. Anglona and cv. Santiago, 0.25 and $0.05 \mathrm{mg} / \mathrm{mL}$ M. sativa saponins and 0.25 and $0.05 \mathrm{mg} / \mathrm{mL}$ M. sativa prosapogenins) showed a very low efficacy $(2 \%-12.5 \%)$, but statistically different $(P<0.001)$ from the untreated controls for which an egg hatch inhibition less than $1 \%$ was registered (Figure 2).

From fecal cultures, Trichostrongylus spp. (40\%), Oesophagostomum spp. (20\%), Cooperia spp. (20\%), Haemonchus spp. (10\%) and Chabertia spp. (10\%) GIS genera were identified. Negative effects of tested saponins against the different nematode genera were approximately similar.

For the calculation of the $\mathrm{EC}_{50}$ and $\mathrm{EC}_{90}$, the best regression line was performed with a logarithmic curve (natural logarithm), with an $\mathrm{R}^{2}$ ranging from 0.87 to 0.93 . With $1.72 \mathrm{mg} / \mathrm{mL} \mathrm{EC}_{50}$ and $3.84 \mathrm{mg} / \mathrm{mL}$ $\mathrm{EC}_{90}$, M. polymorpha cv. Anglona was the most active saponin, followed by M. polymorpha cv Santiago $\left(1.77 \mathrm{mg} / \mathrm{mL} \mathrm{EC}_{50}\right.$ and $\left.4.00 \mathrm{mg} / \mathrm{mL} \mathrm{EC}_{90}\right)$ and $M$. sativa saponins $\left(2.34 \mathrm{mg} / \mathrm{mL} \mathrm{EC}_{50}\right.$ and $4.71 \mathrm{mg} / \mathrm{mL}$ $\mathrm{EC}_{90}$ ). Showing $3.33 \mathrm{mg} / \mathrm{mL} \mathrm{EC}_{50}$ and $8.13 \mathrm{mg} / \mathrm{mL} \mathrm{EC} 90$, M. sativa prosapogenins were the less effective compounds.

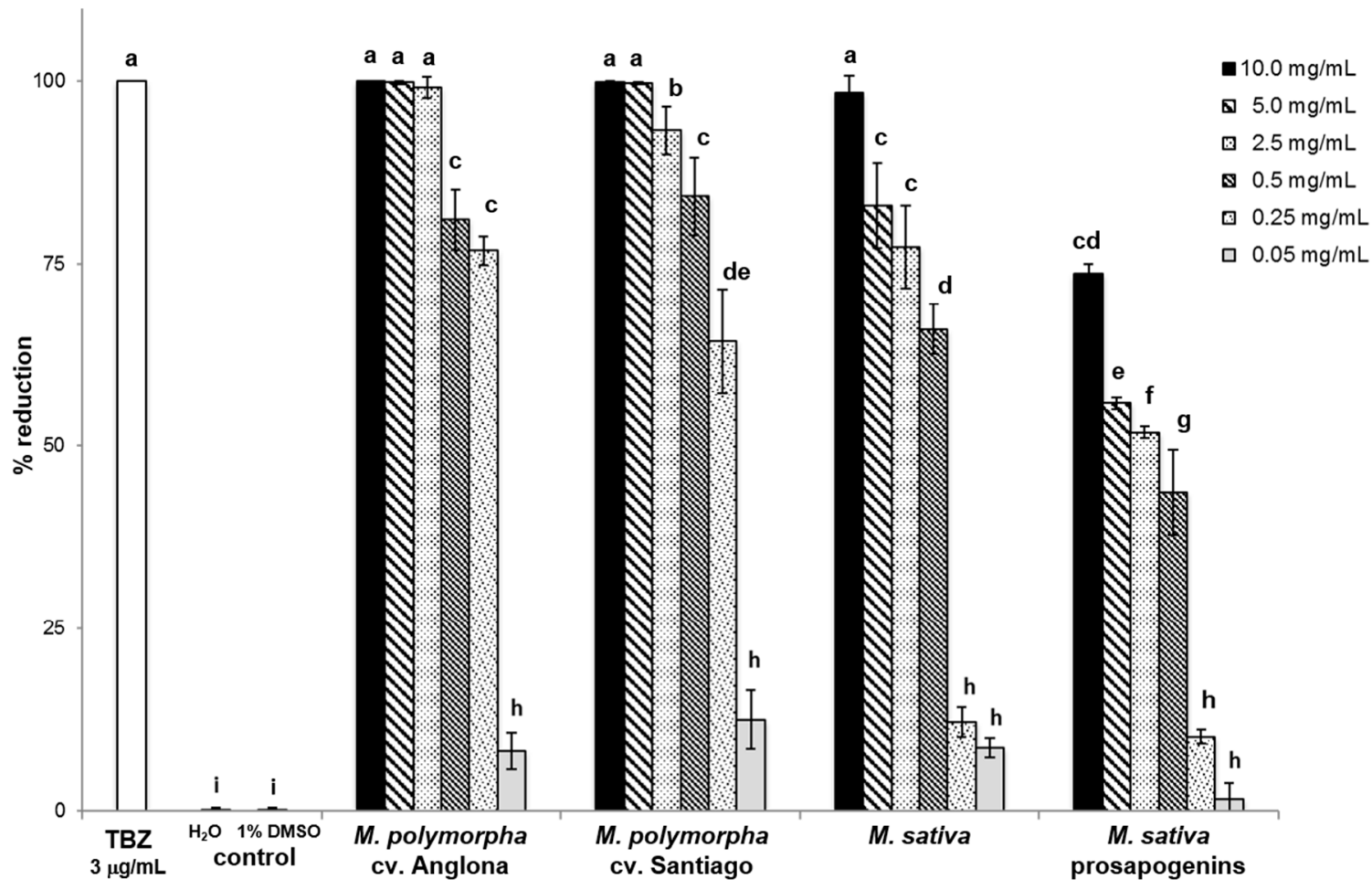

Figure 2. Percentages of egg hatch reduction found for the saponin and prosapogenin mixtures tested at different concentrations (from 10 to $0.05 \mathrm{mg} / \mathrm{mL}$ ) compared to positive (thiabendazole (TBZ) $3 \mu \mathrm{g} / \mathrm{mL})$ and negative $\left(\mathrm{H}_{2} \mathrm{O}\right.$ and $\mathrm{H}_{2} \mathrm{O}-1 \%$ dimethyl sulfoxide (DMSO) $)$ controls. a-i represent a statistical differences.

\section{Discussion}

Results obtained in this study show that all Medicago saponins and prosapogenins evaluated in this study have 'in vitro' inhibiting effects against sheep GIS eggs, although with a different level of 
efficacy, with M. polymorpha saponins as the most active. A dose dependent inhibition effects on egg hatch and development was also observed (Figure 2).

Moreover, the $\mathrm{EC}_{90}$ and $\mathrm{EC}_{50}$ values found for the most active saponins in this study are similar to those reported for other active plant compounds [33]. These results are in agreement with previously reported data, confirming a high ovicidal activity of saponins from Medicago spp. [19]. As observed by [19], when tested at the $10 \mathrm{mg} / \mathrm{mL}$ concentration against donkey GIS eggs, saponins from Medicago spp. show a high activity ( $80 \%-100 \%$ egg hatch reduction) with $M$. polymorpha cv. Anglona and M. sativa as the most active. Differences in saponin activity between sheep and donkey GIS eggs can probably be ascribed to a different susceptibility of sheep and donkey GIS species to tested saponins. The available data from literature also confirm the 'in vitro' anthelmintic activity of this class of compounds against ruminant GIS. The saponins aescin and digitonin [17] and saponin fractions contained in Zizyphus joazeiro [16], Phytolacca icosandra [34] and Agave sisalana [18] showed 'in vitro' ovicidal activity against the nematodes of small ruminants. Similarly, the 'in vitro' ovicidal action of Combretum molle against eggs of $H$. contortus from sheep and of Ipomoea chiliantha, Tocoiena formosa and Aspilia latissima against the eggs of Haemonchus placei from cattle, have been attributed to their saponin content $[33,35]$. Biological effects of saponins are normally ascribed to their specific interaction with the cell membrane, causing changes in the cell permeability [20,36,37]. By this way, saponins may penetrate inside the GIS eggs, altering some biological functions and preventing the normal development of eggs, thus leading to the inhibition of the development of eggs definitively, as proposed by [16]. It has been also hypothesized that these compounds may be able to interfere with enzymatic pathways involved in larval development, which results in larval death [16].

Data obtained in this study on the structure-activity relationship showed that all the Medicago saponins are active compounds against GIS eggs, independently of the involved genins. Comparing results between saponins and related prosapogenins, data here presented indicated that $M$. sativa prosapogenins (monodesmosides) resulted less active than the related saponins (bidesmosides). These results agree with previously reported data on GIS eggs from donkey [19].

The 'in vitro' efficacy of saponins from Medicago spp. in inhibiting the hatching of GIS eggs of sheep and donkey [19], encourage further studies aimed at evaluating their efficacy 'in vivo' as new anthelmintic compounds, as nutraceuticals or as a means to inhibit the environmental development of GIS eggs in order to lower pasture contamination. However, various aspects related to their potential toxicity should be considered. Saponins, in fact, as well as tannins, if ingested in large quantities, are potentially toxic, and may diminish the digestibility of feed [38,39]. However, if taken in moderate concentrations, they can improve nutritional effects [40], and at the same time can reduce the parasitic burden [34]. A previous study [41] showed that a diet containing 1.5\% of saponins from Quillaja saponaria bark may reduce by $38.8 \%$ the sheep fecal egg count (FEC) of GIS eggs when compared to untreated animals. The high 'in vitro' activity of the Medicago saponins evaluated in the present study against sheep GIS eggs may suggest their potential 'in vivo' efficacy at non-toxic dosages.

\section{Materials and Methods}

\subsection{Plant Material, Extraction, Purification and Characterization of Saponin Mixtures}

Medicago plants used in this study were grown at the Research Center for Animal Production and Aquaculture (CREA-ZA, Lodi, Italy). Aerial parts from M. polymorpha cv. Santiago, M. polymorpha cv. Anglona, and M. sativa cv. Equipe were utilized for saponin processing. Leaves were separated from stems and dried at $40{ }^{\circ} \mathrm{C}$ to a constant weight. All samples were ground and used for the successive extractions. Saponins were extracted and purified following general procedures, as previously reported [30-32]. Powdered plant materials (150 g) were separately defatted with $\mathrm{CHCl}_{3}$ in a Soxhlet apparatus for $24 \mathrm{~h}$. Defatted material (100 g) was separately extracted with $80 \% \mathrm{MeOH}$ under reflux for $24 \mathrm{~h}$. The solvent was removed under reduced pressure, and the residue was re-suspended in 30\% 
$\mathrm{MeOH}$. The solution was applied onto a $100 \times 60 \mathrm{~mm}$ RP-18 $(40-63 \mu \mathrm{m})$ column, preconditioned with $30 \% \mathrm{MeOH}$. Elution was carried out with 30\% $\mathrm{MeOH}(500 \mathrm{~mL})$ to remove sugars and some phenolics.

Total saponins were then eluted with $90 \% \mathrm{MeOH}(400 \mathrm{~mL})$ and dried under vacuum. $2.06 \mathrm{~g}$ of saponins were obtained from $M$. polymorpha cv. Anglona (2.1\% yield), $1.72 \mathrm{~g}$ of saponins were obtained from $M$. polymorpha cv. Santiago (1.7\% yield), while $1.48 \mathrm{~g}$ of saponins were obtained from $M$. sativa cv. Equipe (1.5\% yield). In addition, saponins from $M$. sativa were subjected to basic hydrolysis [23] to obtain the related prosapogenins, which were also evaluated in this study. All samples were dissolved in $\mathrm{H}_{2} \mathrm{O}-5 \%$ dimethyl sulfoxide (DMSO), solutions were properly diluted with $\mathrm{H}_{2} \mathrm{O}$ and used in the bioassay at different final concentrations from 0.05 to $10.0 \mathrm{mg} / \mathrm{mL}$. The saponin mixtures, obtained as whitish powders of about $90 \%$ purity, were analyzed by thin layer chromatography (TLC), as previously described [30]. In addition, extracted and purified saponins were characterized for their qualitative and quantitative aglycone composition by gas chromatography (GC) and gas chromatography/mass spectrometry (GC/MS) analyses of derivative sapogenins obtained after acid hydrolysis, as already reported [42]. To obtain information on saponin composition and purity, the saponin mixtures were then analyzed by high-performance liquid chromatography (HPLC), using an external standard method [30], and the results compared with standards of previously purified and identified saponins and data from literature [30-32].

\subsection{Nematode Egg Collection, Purification and Suspension}

Purified GIS eggs were obtained from fecal samples of naturally infected sheep from an organic farm in Tuscany (central Italy). For transport to the laboratory, fecal samples were placed in sealed and refrigerated bags. Fecal microscopic analysis was performed using the Mini-FLOTAC technique [43], with a sensitivity of 20 eggs per gram of feces (EPG). Recovery and suspension of GIS eggs were performed within $3 \mathrm{~h}$ of collection using previously reported methods [44] with some modifications. More specifically, $30 \mathrm{~g}$ of feces were mixed with distilled water and then centrifuged in $50 \mathrm{~mL}$ tubes at $900 \times g$ for $5 \mathrm{~min}$. The supernatant was than eliminated and an $\mathrm{NaCl}$ saturated solution was added to the sediment and centrifuged at $170 \times g$ for $5 \mathrm{~min}$. The supernatant was collected and centrifuged for the last time with distilled water in $15 \mathrm{~mL}$ tubes at $900 \times g$ for $5 \mathrm{~min}$. The supernatant was eliminated in order to obtain the sediment containing the purified eggs that were inspected microscopically to exclude any embryonation that had begun, then they were counted, diluted in distilled water to the final concentration of about $400 \mathrm{eggs} / \mathrm{mL}$ and used immediately in the bioassay. Finally, fecal cultures were also performed by using the same pooled fecal samples employed for obtaining gastrointestinal strongyles eggs, to the aim of identifying GIS nematodes at the genus level. Fecal samples were cultured in an incubator at $25^{\circ} \mathrm{C}$ for seven days, and larvae were recovered by the Baermann technique and identified according to the key and description given by [45].

\subsection{Evaluation of the 'In Vitro' Anthelmintic Activity of Saponins}

The Egg Hatch Test (EHT) was performed to evaluate the 'in vitro' anthelmintic activity of saponin and prosapogenin samples. In EHT the effectiveness of the substances is evaluated based on their ability to inhibit the development and hatching of parasite eggs [44,46]. In the present work the EHT was carried as in the previously reported methods $[35,44,46]$, with some minor modifications. In detail, 24-well, flat-bottomed microplates were used, and $0.5 \mathrm{~mL}$ of distilled water containing approximately 200 eggs were placed in each well. All the test samples were treated with $0.5 \mathrm{~mL}$ of the different saponin solutions to obtain the reported final saponin concentration. Positive controls contained the same amount of GIS eggs and the anthelmintic drug TBZ (2-(4-Thiazoly) Benzimidazole (Thiabendazole) minimum 99\%, Sigma S.r.l., Milan, Italy) at the final concentration of $3 \mu \mathrm{g} / \mathrm{mL}$ in 1\% DMSO. Two different negative controls were prepared by adding to the egg suspension $0.5 \mathrm{~mL}$ of distilled water and $0.5 \mathrm{~mL}$ of $1 \%$ DMSO. The plates were then incubated at $25{ }^{\circ} \mathrm{C}$ in darkness and $80 \%$ humidity 
for $48 \mathrm{~h}$, and the number of eggs and of the first-stage larvae (L1) in each well was microscopically counted. The percentage of egg hatch reduction was calculated using the following formula:

$$
\text { number of eggs/(number of L1 + number of eggs) } \times 100
$$

All experiments were performed in triplicate in three independent assays.

\subsection{Statistical Analysis}

Results from all experiments were statistically analyzed and compared. Statistical analysis was performed using the Statistical Analysis System (SAS) program. To perform the statistical analysis of the obtained data, a one-way analysis of variance (ANOVA) test with $5 \%$ significance $(P<0.05)$, was used. Significant results were further tested with the Tukey post-hoc test $(P<0.05)$. The determination of $\mathrm{EC}_{50}$ and $\mathrm{EC}_{90}$ concentrations was done through non-linear regression analysis by using XLSTAT ${ }^{\circledR}$.

\subsection{Ethical Declaration}

This study has not included animal experiment. Sheep fecal samples used for the evaluations performed in this study have been collected with the consensus of the farm owner. Authors declare that the work has been carried out in adherence to a high standard of veterinary care.

Author Contributions: Conceptualization, A.T., M.M. and S.P.; methodology, A.T., M.M. and S.P.; software, S.M.; formal analysis, A.T.; investigation, M.M. and S.P.; data curation, S.M.; interpretation of data and writing the original draft, A.T., M.M., S.P., S.M. All authors have read and agreed to the published version of the manuscript.

Funding: This research received no external funding.

Conflicts of Interest: The authors declare no conflict of interest.

\section{References}

1. Kenyon, F.; Rinaldi, L.; McBean, D.; Pepe, P.; Bosco, A.; Melville, L.; Devin, L.; Mitchell, G.; Ianniello, D.; Charlier, J.; et al. Pooling sheep faecal samples for the assessment of anthelmintic drug efficacy using McMaster and Mini-FLOTAC in gastrointestinal strongyle and Nematodirus infection. Vet. Parasitol. 2016, 225, 53-60. [CrossRef] [PubMed]

2. Charlier, J.; van der Voort, M.; Kenyon, F.; Skuce, P.; Vercruysse, J. Chasing helminths and their economic impact on farmed ruminants. Trends Parasitol. 2014, 30, 361-367. [CrossRef] [PubMed]

3. Whittaker, J.H.; Carlson, S.A.; Jones, D.E.; Brewer, M.T. Molecular mechanisms for anthelmintic resistance in strongyle nematode parasites of veterinary importance. J. Vet. Pharmacol. Ther. 2017, 40, 105-115. [CrossRef] [PubMed]

4. Papadopoulos, E.; Gallidis, E.; Ptochos, S. Anthelmintic resistance in sheep in Europe: A selected review. Vet. Parasitol. 2012, 189, 85-88. [CrossRef]

5. Torres-Acosta, J.F.; Mendoza-de-Gives, P.; Aguilar-Caballero, A.J.; Cuéllar-Ordaz, J.A. Anthelmintic resistance in sheep farms: Update of the situation in the american continent. Vet. Parasitol. 2012, 189, 89-96. [CrossRef]

6. Sales, N.; Love, S. Resistance of Haemonchus sp. to monepantel and reduced efficacy of a derquantel/abamectin combination confirmed in sheep in NSW, Australia. Vet. Parasitol. 2016, 228, 193-196. [CrossRef]

7. Vokrál, I.; Michaela, S.; Radka, P.; Jirí, L.; Lukás, P.; Dominika, S.; Katerina, L.; Barbora, S.; Lenka, S. Ivermectin environmental impact: Excretion profile in sheep and phytotoxic effect in Sinapis alba. Ecotoxicol. Environ. Saf. 2019, 169, 944-949. [CrossRef]

8. Kang, J.; Park, S.J.; Park, H.C.; Hossain, M.A.; Kim, M.A.; Son, S.W.; Lim, C.M.; Kim, T.W.; Cho, B.H. Multiresidue screening of veterinary drugs in meat, milk, egg, and fish using liquid chromatography coupled with ion trap time-of-flight mass spectrometry. App. Biochem. Biotechnol. 2017, 182, 635-652. [CrossRef]

9. Hoste, H.; Torres-Acosta, J.F.J. Non chemical control of helminths in ruminants: Adapting solutions for changing worms in a changing world. Vet. Parasitol. 2011, 180, 144-154. [CrossRef] 
10. Charlier, J.; Thamsborg, S.M.; Bartley, D.J.; Skuce, P.J.; Kenyon, F.; Geurden, T.; Hoste, H.; Williams, A.R.; Sotiraki, S.; Höglund, J.; et al. Mind the gaps in research on the control of gastrointestinal nematodes of farmed ruminants and pigs. Transbound. Emerg. Dis. 2018, 65, 217-234. [CrossRef]

11. Giovanelli, F.; Mattellini, M.; Fichi, G.; Flamini, G.; Perrucci, S. In vitro anthelmintic activity of four plant-derived compounds against sheep gastrointestinal nematodes. Vet. Sci. 2018, 5, 78. [CrossRef] [PubMed]

12. Cortes-Morales, J.A.; Olmedo-Juárez, A.; Trejo-Tapia, G.; González-Cortazar, M.; Domínguez-Mendozad, B.E.; Mendoza-de Gives, P.; Zamilpa, A. In vitro ovicidal activity of Baccharis conferta Kunth against Haemonchus contortus. Experim. Parasitol. 2019, 197, 20-28. [CrossRef] [PubMed]

13. Esteban-Ballesteros, M.; Sanchis, J.; Gutiérrez-Corbo, C.; Balaña-Fouce, R.; Rojo-Vázquez, F.A.; González-Lanza, C.; Martínez-Valladar, M. In vitro anthelmintic activity and safety of different plant species against the ovine gastrointestinal nematode Teladorsagia circumcincta. Res. Vet. Sci. 2019, 123, 153-158. [CrossRef] [PubMed]

14. Vargas-Magaña, J.J.; Torres-Acosta, J.F.J.; Aguilar-Caballero, A.J.; Sandoval-Castro, C.A.; Hoste, H.; Chan-Pérez, J.I. Anthelmintic activity of acetone-water extracts against Haemonchus contortus eggs: Interactions between tannins and other plant secondary compounds. Vet. Parasitol. 2014, 206, 322-332. [CrossRef]

15. Spiegler, V.; Liebau, E.; Hensel, A. Medicinal plant extracts and plant-derived polyphenols with anthelmintic activity against intestinal nematode. Nat. Prod. Rep. 2017, 34, 627-643. [CrossRef]

16. Cavalcanti Gomes, D.C.; de Lima, H.G.; Vaz, A.V.; Santos, N.S.; Santos, F.O.; Dias, Ê.R.; Botura, M.B.; Branco, A.; Batatinha, M.J. In vitro anthelmintic activity of the Zizyphus joazeiro bark against gastrointestinal nematodes of goats and its cytotoxicity on Vero cells. Vet. Parasitol. 2016, 226, 10-16. [CrossRef]

17. Santos, A.C.V.; Santos, F.O.; Lima, H.G.; Silva, G.D.D.; Uzêda, R.S.; Dias, Ê.R.; Branco, A.; Cardoso, K.V.; David, J.M.; Botura, M.B.; et al. In vitro ovicidal and larvicidal activities of some saponins and flavonoids against parasitic nematodes of goats. Parasitology 2018, 145, 1884-1889. [CrossRef]

18. Botura, M.B.; dos Santos, J.D.; da Silva, G.D.; de Lima, H.G.; de Oliveira, J.V.A.; de Almeida, M.A.O.; Batatinha, M.J.M.; Branco, A. In vitro ovicidal and larvicidal activity of Agave sisalana Perr. (sisal) on gastrointestinal nematodes of goats. Vet. Parasitol. 2013, 192, 211-217. [CrossRef]

19. Maestrini, M.; Tava, A.; Mancini, S.; Salari, F.; Perrucci, S. In vitro anthelmintic activity of saponins derived from Medicago spp. plants against donkey gastrointestinal nematodes. Vet. Sci. 2019, 6, 35. [CrossRef]

20. Tava, A.; Avato, P. Chemical and biological activity of triterpene saponins from Medicago species. Nat. Prod. Comm. 2006, 1, 1159-1180. [CrossRef]

21. Doligalska, M.; Józwicka, K.; Kiersnowska, M.; Mroczek, A.; Paczkowski, C.; Janiszowska, W. Triterpenoid saponins affect the function of P-glycoprotein and reduce the survival of the free-living stages of Heligmosomoides bakeri. Vet. Parasitol. 2011, 179, 144-151. [CrossRef] [PubMed]

22. Vo, N.N.Q.; Fukushima, E.O.; Muranaka, T. Structure and hemolytic activity relationships of triterpenoid saponins and sapogenins. J. Nat. Med. 2017, 71, 50-58. [CrossRef] [PubMed]

23. Avato, P.; Bucci, R.; Tava, A.; Vitali, C.; Rosato, A.; Bialy, Z.; Jurzysta, M. Antimicrobial activity of saponins from Medicago sp.: Structure-activity relationship. Phytoter. Res. 2006, 20, 454-457. [CrossRef] [PubMed]

24. D'Addabbo, T.; Carbonara, T.; Leonetti, P.; Radicci, V.; Tava, A.; Avato, P. Control of plant parasitic nematodes with active saponins and biomass from Medicago sativa. Phytochem. Rev. 2011, 10, 503-519. [CrossRef]

25. Abbruscato, P.; Tosi, S.; Crispino, L.; Biazzi, E.; Menin, B.; Picco, A.M.; Pecetti, L.; Avato, P.; Tava, A. Triterpenoid Glycosides from Medicago sativa as Antifungal Agents against Pyricularia oryzae. J. Agric. Food Chem. 2014, 62, 11030-11036. [CrossRef] [PubMed]

26. Avato, P.; Migoni, D.; Argentieri, M.; Fanizzi, F.P.; Tava, A. Activity of saponins from Medicago species against HeLa and MCF-7 cell lines and their capacity to potentiate cisplatin effect. Anticanc. Agent Med. Chem. 2017, 17, 1508-1518. [CrossRef] [PubMed]

27. Piano, E.; Pecetti, L. Minor legume species. In Fodder Cops and Amenity Grasses, 2nd ed.; Boller, B., Posselt, U.K., Veronesi, F., Eds.; Handbook of Plant Breeding Series; Springer: New York, NY, USA, 2010; Volume 5, pp. 477-500.

28. Bialy, Z.; Jurzysta, M.; Oleszek, W.; Piacente, S.; Pizza, C. Saponins in alfalfa (Medicago sativa L.) root and their structural elucidation. J. Agric. Food Chem. 1999, 47, 3185-3192. [CrossRef]

29. Pecetti, L.; Tava, A.; Romani, M.; De Benedetto, M.G.; Corsi, P. Variety and environment effects on the dynamics of saponins in lucerne (Medicago sativa L.). Eur. J. Agron. 2006, 25, 187-192. [CrossRef] 
30. Tava, A.; Pecetti, L.; Romani, M.; Mella, M.; Avato, P. Triterpenoid glycosides from the leaves of two cultivars of Medicago polymorpha L. J. Agric. Food Chem. 2011, 59, 6142-6149. [CrossRef]

31. Tava, A.; Mella, M.; Avato, P.; Argentieri, M.P.; Bialy, Z.; Jurzysta, M. Triterpenoid glycosides from the leaves of Medicago arborea L. J. Agric. Food Chem. 2005, 53, 9954-9965. [CrossRef]

32. Bialy, Z.; Jurzysta, M.; Mella, M.; Tava, A. Triterpene saponins from the roots of Medicago hybrida. J. Agric. Food Chem. 2006, 54, 2520-2526. [CrossRef] [PubMed]

33. Borges, D.G.L.; Echeverria, J.T.; de Oliveira, T.L.; Heckler, R.P.; de Freitas, M.G.; Damasceno-Junior, G.A.; Carollo, C.A.; De Almeida Borges, F. Discovery of potential ovicidal natural products using metabolomics. PLoS ONE 2019, 14, e0211237. [CrossRef] [PubMed]

34. Hernandez-Villegas, M.M. Ovicidal and larvicidal activity of the crude extracts from Phytolacca icosandra against Haemonchus contortus. Vet. Parasitol. 2011, 179, 100-106. [CrossRef] [PubMed]

35. Ademola, I.O.; Eloff, J.N. In vitro anthelmintic activity of Combretum molle (R. Br. ex G. Don) (Combretaceae) against Haemonchus contortus ova and larvae. Vet. Parasitol. 2010, 169, 198-203. [CrossRef] [PubMed]

36. Hostettmann, K.; Marston, A. Saponins: Chemistry and Pharmacology of Natural Products; Phillipson, J.D., Baxter, H., Eds.; Cambridge University Press: Cambridge, UK, 1995.

37. Sprag, S.G.; Light, M.E.; van Staden, J. Biological activities and distribution of plant saponins. J. Ethnopharm. 2004, 94, 219-243. [CrossRef]

38. Provenza, F.D.; Burritt, E.A.; Clausen, T.P.; Bryant, J.P.; Reichardt, P.B.; Distel, R.A. Conditioned flavor aversion: A mechanism for goats to avoid condensed tannins in blackbrush. Am. Nat. 1990, 136, 810-828. [CrossRef]

39. Dawson, J.M.; Buttery, P.J.; Jenkins, D.; Wood, C.D.; Gill, M. Effects of dietary quebracho tannin on nutrient utilization and tissue metabolism in sheep and rats. J. Sci. Food Agric. 1999, 79, 1423-1430. [CrossRef]

40. Hu, W.L.; Liu, J.X.; Ye, J.A.; Wu, Y.M.; Guo, Y.Q. Effect of tea saponin on rumen fermentation in vitro. Anim. Feed Sci. Technol. 2005, 120, 333-339. [CrossRef]

41. Copani, G.; Hall, J.O.; Miller, J.; Priolo, A.; Villalba, J.J. Plant secondary compounds as complementary resources: Are they always complementary? Oecologia 2013, 172, 1041-1049. [CrossRef]

42. Tava, A.; Biazzi, E.; Mella, M.; Quadrelli, P.; Avato, P. Artefact formation during acid hydrolysis of saponins from Medicago spp. Phytochemistry 2017, 238, 116-127. [CrossRef]

43. Rinaldi, L.; Levecke, B.; Bosco, A.; Ianniello, D.; Pepe, P.; Charlier, J.; Cringoli, G.; Vercruysse, J. Comparison of individual and pooled faecal samples in sheep for the assessment of gastrointestinal strongyle infection intensity and anthelmintic drug efficacy using McMaster and Mini-FLOTAC. Vet. Parasitol. 2014, 205, 216-223. [CrossRef] [PubMed]

44. Coles, G.C.; Jackson, F.; Pomroy, W.E.; Prichard, R.K.; von Samson-Himmelstjerna, G.; Silvestre, A.; Taylor, M.A.; Vercruysse, J. The detection of anthelmintic resistance in nematodes of veterinary importance. Vet. Parasitol. 2006, 136, 167-185. [CrossRef] [PubMed]

45. Ministry of Agriculture, Fisheries and Food (MAFF). Manual of Veterinary Parasitological Laboratory Techniques; Her Majesty's Stationary Office (HMSO): London, UK, 1986; pp. 1-152.

46. Coles, G.C.; Bauer, C.; Borgsteede, F.H.; Geerts, S.; Klei, T.R.; Taylor, M.A.; Waller, P.J. World Association for the Advancement of Veterinary Parasitology (W.A.A.V.P.) methods for the detection of anthelmintic resistance in nematodes of veterinary importance. Vet. Parasitol. 1992, 44, 35-44. [CrossRef]

Sample Availability: Samples of the saponin mixtures are available from the authors. 